\title{
Leukemia Epidemiology in Karbala province of Iraq
}

\author{
Ahmed Mjali', Haider Hasan Jaleel Al-Shammari², Nareen Tawfeeq Abbas ${ }^{3}$, \\ Zahraa Deheyaa Azeez ${ }^{4}$, Saja Khudhair Abbas ${ }^{1}$
}

${ }^{1}$ Department of Hematology /Oncology, Al- Hussein Medical City, Karbala, Iraq. ${ }^{2}$ Baghdad University, College of Medicine, Baghdad, Iraq. ${ }^{3}$ Department of Hematology, Hiwa hematology/Oncology Hospital, Sulaymaniyah, Iraq. ${ }^{4}$ Gynecology and Obstetrics Teaching Hospital, Karbala, Iraq.

\begin{abstract}
Objective: Investigate epidemiology of leukemia in Karbala province of Iraq, compare and identify possible changes with other populations. Methods: This was retrospective descriptive study for more than 400 leukemia patients in Karbala province from November 2011 to May 2018 with evaluation of age, gender distribution, types distribution, and frequency distribution types of leukemia according to age and gender. Result: About 402 patients with leukemia were retrospectively enrolled in this study at median age of 30 years. Males accounted for a higher proportion of leukemia patients, $58.2 \%$ compared to $41.8 \%$ females, with a male to female ratio of nearly 1.4:1. Acute lymphoblastic leukemia (ALL) was the most prevalent in the study group, contributing $41 \%$ (median age 10 years), followed by chronic myeloid leukemia (CML) $24.1 \%$ (median age 42 years), acute myeloid leukemia (AML) 19.2\% (median age 36 years) and chronic lymphocytic leukemia(CLL) of less frequent type which contributed only $15.7 \%$ (median age 60 years). Conclusion: This is the first statistical study of leukemia in Karbala. It can be used as basic information to investigate epidemiological characteristics, to evaluate progress in recent years and to develop future leukemia strategies. More statistical leukemia analyses in Iraq are needed.
\end{abstract}

Keywords: Leukemia- Epidemiology- Karbala- Iraq

Asian Pac J Cancer Care, 4 (4), 135-139

\section{Introduction}

In 2012 , there were about 352,000 new cases of leukemia ( 2.5 percent of all new cancer cases) and 265,000 deaths ( 3.2 percent of all cases).The lowest incidence rates in Middle and WestAfrica (less than 3 per 100,000 males and less than 2 per 100,000 females) and the highest in North America and Australia / New Zealand (more than 10 per 100,000 males and 7 per 100,000 females). Sub Saharan Africa's estimated low incidence rates may be due to a failure to diagnose the disease in old or very young patients [1].

In Iraq, leukemia represents the fourth common cancer in both male and female. In 2009 Iraqi Cancer Board recorded 13951 cases of leukemia in Iraq in the years from 1991 to 2009 representing $6.59 \%$ of new cases [2]. In Karbala province which is a town in central Iraq, about $100 \mathrm{~km}$ southwest of Baghdad (Figure 1) [3], and has an estimated population of 1013254 people in 2009, leukemia
Submission Date: 04/08/2019 Acceptance Date: 07/12/2019

was the sixth common cancer with incidence rate 3.26 $/ 100000$ Population [2].

Leukemia is usually had four main categories, with different presentations and outcomes: acute lymphocytic leukemia, chronic lymphocytic leukemia, acute myeloid leukemia, and chronic myeloid leukemia. Males have a slightly higher incidence of leukemia than females. Leukemia rates also vary geographically and ethnically. In the US, the Caucasian incidence is higher than in African - Americans and Hispanics. The lowest rate of incidence among Americans / Alaskans [4].

Ionizing radiation exposure, chemicals like benzene, pesticides, chemotherapy, smoking cigarettes, viral infection and genetic disorders are recognized as leukemia risk factors [5-11]. However, these risk factors can only explain minority cases and the etiology of leukemia remains largely unknown [12].

In this study, we investigated leukemia distribution among the population in Karbala province of Iraq from

Corresponding Author:

Dr. Ahmed Mjali

Department of Hematology /Oncology, Al- Hussein Medical City, Karbala, Iraq.

Email: ahmedmajly@yahoo.com 
2011 to 2018.It can help to provide basic information to investigate epidemiological characteristics, to assess progress in recent years and to develop future leukemia treatment strategies.

\section{Materials and Methods}

We conducted a retrospective, descriptive, epidemiological study of leukemia patients in the Karbala province, diagnosed between November 2011 and May 2018. The data for this study were obtained from cancer registry department in Al Hussein Cancer Centre in Karbala, which was established in November 2011 and there were no accurate leukemia data available before. This Centre covers Karbala population and most of children and adults with leukemia were referred to this center for treatment. It is presently the only available source of information and most of patients with leukemia attended the center were enrolled in this study. Data provided information about gender of patients, diagnosis and the years of diagnoses.

Diagnoses were made on peripheral blood films and morphology of bone marrow including cytochemical staining and immunophenotyping. Patient with non-conclusive result was excluded from this study. Selected topic was accepted by scientific committee; official acceptance was taken from health authorities to conduct this study. Collected information was kept confidential.

\section{Statistical analysis}

The statistical package for social sciences (SPSS) for windows, version 24 was used for entering, managing and analysis of data. Descriptive statistics presented as count (frequency), proportions, median and interquartile range (IQR), findings presented in tables and figure using MS-office software version 2013.

\section{Results}

A total of 402 patients diagnosed with leukemia were retrospectively analyzed during our study. Patients ages were between 1 year and 90 years, 234 were males $(58.2 \%)$ and 168 were females $(41.8 \%)$, with an $\mathrm{M} / \mathrm{F}$ ratio of 1.4:1. Among all leukemia cases, $22.6 \%(\mathrm{n}=91)$ were below 10 years. The median age of diagnosis was 30 years for all cases (Table 1).

Regarding the distribution of types of leukemia, ALL was the more prevalent type among the studied group, contributed (41\%, median age 10 years), followed by CML (24.1\%, median age 42), AML (19.2\%, median age 36 years) and the less frequent type was CLL which contributed only $(15.7 \%$, median age 60 years) [Figure 2 and Table 2].

The distribution of types of leukemia according to age group revealed that ALL was the more prevalent type of leukemia among the younger age groups it was found in $87.9 \%$ of leukemia cases in the age $\leq 10$ years.AML was more prevalent in the age groups $31-40$ years, and $61-70$ years where it was found in $32.6 \%$ and $31.9 \%$ of cases in these two age groups, respectively.
Table 1. Age and Gender Distribution of 402 Cases of Leukemia Reported During the Period 2011 - 2018

\begin{tabular}{lccc}
\hline Variable & & Count & $\%$ \\
\hline Age (year) & $\leq 10$ & 91 & $22.6 \%$ \\
& $11-20$ & 72 & $17.9 \%$ \\
& $21-30$ & 43 & $10.7 \%$ \\
& $31-40$ & 43 & $10.7 \%$ \\
& $41-50$ & 44 & $10.9 \%$ \\
& $51-60$ & 42 & $10.4 \%$ \\
& $61-70$ & 47 & $11.7 \%$ \\
& $>70$ & 20 & $5.0 \%$ \\
Gender & Median (IQR*) & $30(12-54)$ & - \\
& Male & 234 & $58.2 \%$ \\
& Female & 168 & $41.8 \%$ \\
\hline
\end{tabular}

*IQR, Interquartile range

CLL was more prevalent among those aged more than 50 years old with $45 \%$ of leukemia cases. Interestingly, none of the cases at the age of 30 years or below had CLL. For the CML was prevalence among those 41-50 years presenting $50 \%$ while representing only $2 \%$ of leukemia in patient below 10 years old (Table 3 ).

\section{Discussion}

The quality and ability to access to the health systems can explain the geographical differences in leukemia, although etiological factors including gene-environment interactions would probably play a role. Global leukemia rates in males were generally higher than females with a total M/F of 1:4, which was the same as in our study [13].

In our study ALL was the more prevalent type among the studied group; contributed $41 \%$, followed by CML $24.1 \%$,AML $19.2 \%$ and the less frequent type was CLL which contributed only $15.7 \%$.In study done in Sulaymaniyah province of Iraq ALL was the most

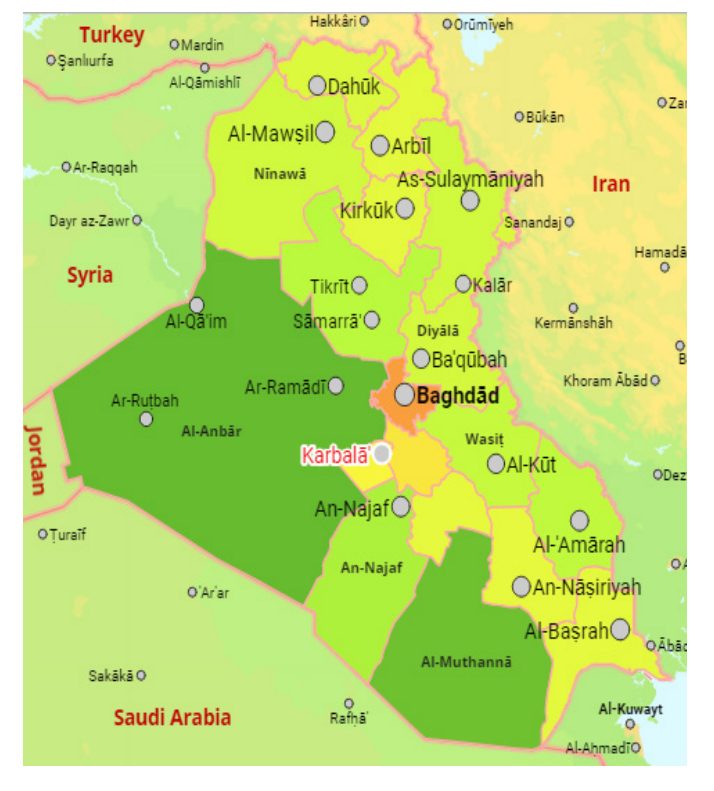

Figure 1. Map of Iraq3 
Table 2. Distribution Pattern, Median Age at Diagnosis of Leukemia in Karbala Province

\begin{tabular}{lccc}
\hline Leukemia types & Number of cases & Distribution (\%) & Median age (year) \\
\hline ALL & 165 & $41 \%$ & 10 \\
CLL & 63 & $15.7 \%$ & 60 \\
AML & 77 & $19.2 \%$ & 36 \\
CML & 97 & $24.1 \%$ & 42 \\
Total & 402 & 100 & 30 \\
\hline
\end{tabular}

Table 3. Frequency Distribution Types of Leukemia According to the Type, Age and Gender from 2011 to 2018

\begin{tabular}{|c|c|c|c|c|c|c|c|c|c|}
\hline \multirow{3}{*}{ Age (year) } & \multirow{3}{*}{$\begin{array}{c}\text { Total } \\
\text { Cases }\end{array}$} & \multicolumn{8}{|c|}{ Type of leukemia } \\
\hline & & \multicolumn{2}{|c|}{ ALL } & \multicolumn{2}{|c|}{ AML } & \multicolumn{2}{|c|}{ CLL } & \multicolumn{2}{|c|}{ CML } \\
\hline & & Count & $\%$ & Count & $\%$ & Count & $\%$ & Count & $\%$ \\
\hline$\leq 10$ & 91 & 80 & 87.9 & 9 & 9.9 & 0 & 0.0 & 2 & 2.2 \\
\hline $11-20$ & 72 & 50 & 69.4 & 15 & 20.8 & 0 & 0.0 & 7 & 9.7 \\
\hline $21-30$ & 43 & 19 & 44.2 & 7 & 16.3 & 0 & 0.0 & 17 & 39.5 \\
\hline $31-40$ & 43 & 7 & 16.3 & 14 & 32.6 & 3 & 7.0 & 19 & 44.2 \\
\hline $41-50$ & 44 & 4 & 9.1 & 8 & 18.2 & 10 & 22.7 & 22 & 50.0 \\
\hline $51-60$ & 42 & 3 & 7.1 & 5 & 11.9 & 21 & 50.0 & 13 & 31.0 \\
\hline $61-70$ & 47 & 1 & 2.1 & 15 & 31.9 & 19 & 40.4 & 12 & 25.5 \\
\hline$>70$ & 20 & 1 & 5.0 & 4 & 20.0 & 10 & 50.0 & 5 & 25.0 \\
\hline \multicolumn{10}{|l|}{ Gender } \\
\hline Male & 234 & 101 & 43.2 & 42 & 17.9 & 39 & 16.7 & 52 & 22.2 \\
\hline Female & 168 & 64 & 38.1 & 35 & 20.8 & 24 & 14.3 & 45 & 26.8 \\
\hline
\end{tabular}

common type of leukemia with $44 \%$ in all cases, CML was the second type with $20 \%$ of cases followed by CLL, $18 \%$ and AML, $17 \%$ [14].

In Croatia, the most common type of leukemia was CLL, which accounted for $42 \%$ of leukemia, followed by AML with $27 \%$, ALL with $17 \%$ and CML with $14 \%$ [15]. In Bangladesh, on the other hand, AML was the most prevalent hematological malignancy $28.3 \%$ followed by CML $18.2 \%$, ALL $14.1 \%$ and CLL $3.7 \%$ was the least common [16].

In Karbala ALL was the more prevalent type of leukemia among the younger age groups of 30 years or below; it was found in $87.9 \%$ of leukemia cases in the age $\leq 10$ years with median age of 10 years. This is close to study done by (Elew et al., 2009) in Baghdad

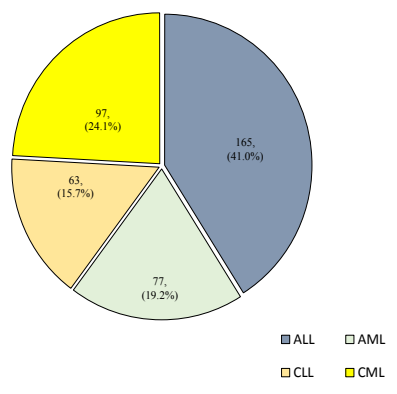

Figure 2. Distribution of Types of Leukemia of 402 Cases During the Period 2011 - 2018 that showed ALL represent $90.5 \%$ of leukemia cases below 10 years old [17]. This result was also closed to data in the United States with a median age of only 15 years and about $60 \%$ of patients were under 20 years of age. Although in India, about 60 to $85 \%$ of all reported leukemia was ALL [18-19].

Incidence of AML in North America, Oceania and Europe is relatively common, whereas adults AML in Latin America and Asia is uncommon. AML affects older people with a median age at present in Western countries around 65 years [4-20]. While in our study median age was only 36 years old that closer to previous study in Baghdad with $\sim 33$ years and studies in Bangladesh with $~ 35$ years and India with $\sim 30$ years [16-21-22].

The median age of CML in Karbala was 42 years, which is older than previous study done in Iraq with median age of $\sim 37$ years. Our result was closer to median age in Turkey 46 years and Bangladesh was 40 years old. Interestingly much younger than of US with median age of 65years and Europe 55 years old [16-23-27].

CLL is a rare hematological disorder in Asia, although it represents the most common leukemia in the West that affects elderly people. In the US, for example, CLL accounts for about $\sim 34 \%$ of leukemia cases [4-28].

CLL median age in Karbala was 60 years old and none of the cases at the age of 30 years or below, this close to previous studies in Iraq with median age $\sim 60$ years 29. Our result also was closer to the median age in Turkey with 63years, India median age with $\sim 60$ years and Bangladesh 60 years old [16-30-32]

While our study median age was younger than that in 
the USA, Europe and Australia which is approximately 70 years of age [32-34].

In conclusion distribution of leukemia in Karbala differs from other countries, with younger median age than western countries. This may be explained by fact that $>58 \%$ of population under 25 years old and about $3.4 \%$ of population above 65 years. 35 More studies are needed to understand the leukemia patterns and dissemination in Iraq and recognize biology, genetics \& possible risk factor in Iraqi patients.

\section{Acknowledgements}

We would like to thank Mrs.Afnan Al Wakeel and Mr. Hekmat Hamada Baqir from Karbala Cancer Registry Center, without their help this study couldn't see the light of day.

\section{References}

1. Ferlay J, Soerjomataram I, Dikshit R, Eser S, Mathers C, Rebelo M, Parkin DM, Forman D, Bray F. Cancer incidence and mortality worldwide: sources, methods and major patterns in GLOBOCAN 2012. Int J Cancer. 2015 Mar 1; 136(5).

2. Iraqi Cancer Board. Result of Iraqi Cancer Registry 2009. Baghdad: Iraqi Cancer Registry Center, Ministry of Heaith.2012.

3. ThomasBrinkhoff: city population [cited 2018 June 4].Available from:http://www.citypopulation.de/Iraq-Cities. html.

4. Rodriguez-Abreu D, Bordoni A, Zucca E. Epidemiology of hematological malignancies. Ann Oncol. 2007 Feb 1; 18(suppl_1):i3-8.

5. Leuraud K, Richardson DB, Cardis E, Daniels RD, Gillies M, O'hagan JA, Hamra GB, Haylock R, Laurier D, Moissonnier $\mathrm{M}$, Schubauer-Berigan MK. Ionizing radiation and risk of death from leukaemia and lymphoma in radiation-monitored workers (INWORKS): an international cohort study. Lancet Haematol. 2015 Jul 1;2(7):e276-81.

6. Rothman N, Smith MT, Hayes RB, Traver RD, Hoener BA, Campleman S, Li GL, Dosemeci M, Linet M, Zhang L, $\mathrm{Xi}$ L. Benzene poisoning, a risk factor for hematological malignancy, is associated with the NQO1 $609 \mathrm{C} \rightarrow \mathrm{T}$ mutation and rapid fractional excretion of chlorzoxazone. Cancer Res. 1997 Jul 15; 57(14):2839-42.

7. Ma X, Buffler PA, Gunier RB, Dahl G, Smith MT, ReinierK, Reynolds P. Critical windows of exposure to household pesticides and risk of childhood leukemia. Environ Health Perspect. 2002 Sep; 110(9):955.

8. Ezoe S. Secondary leukemia associated with the anti-cancer agent, etoposide, a topoisomerase II inhibitor. Int J Environ Res Public Health. 2012 Jul 10; 9(7):2444-53.

9. Brownson RC, Novotny TE, Perry MC. Cigarette smoking and adult leukemia: a meta-analysis. Arch Intern Med. 1993 Feb 22; 153(4):469-75.

10. ZurHausen H. Viruses in human cancers.Science. 1991 Nov 22; 254(5035):1167-73.

11. Hamblin TJ, Davis Z, Gardiner A, Oscier DG, Stevenson FK.UnmutatedIg $\mathrm{VH}$ genes are associated with a more aggressive form of chronic lymphocytic leukemia. Blood. 1999 Sep 15; 94(6):1848-54.

12. Deschler B, Lübbert M. Acute myeloid leukemia: epidemiology and etiology. Cancer. 2006 Nov 1;
107(9):2099-107.

13. Miranda-Filho A, Piñeros M, Ferlay J, Soerjomataram I, Monnereau A, Bray F. Epidemiological patterns of leukaemia in 184 countries: a population-based study. Lancet Haematol. 2018 Jan 31; 5(1):e14-24.

14. Karim ZA, Khidhir KG, Ahmed RA, Hassan HA, Karim DO. Leukemia Study in Sulaymaniyah Province, Kurdistan, Iraq.Chin Med J. 2016 Jan 20; 129(2):244.

15. Novak I, Jakšić O, Kuliš T, Batinjan K, Znaor A. Incidence and mortality trends of leukemia and lymphoma in Croatia, 1988-2009. Croat Med J. 2012 Apr 15; 53(2):115-23.

16. Hossain MS, Iqbal MS, Khan MA, Rabbani MG, Khatun H, Munira S, Miah MM, Kabir AL, Islam N, Dipta TF, Rahman F. Diagnosed hematological malignancies in Bangladesh-a retrospective analysis of over 5000 cases from 10 specialized hospitals. BMC cancer. 2014 Dec; 14(1):438.

17. Elew GF, Mahmood AH, Mohammad TK, Al-Khalidi SJ.A study on the prevalence of acute leukemia among a group of Iraqi patients.Journal of Al-Nahrain University-Science. 2009; 12(2):107-12.

18. National Cancer Institute, Cancer Stat Facts (2015).Acute Lymphoblastic Leukemia[cited 2018 June 5].Available from:https://seer.cancer.gov/statfacts/html/alyl.html.

19. Arora RS, Eden TO, Kapoor G. Epidemiology of childhood cancer in India. Indian J Cancer. 2009 Oct 1; 46(4):264.

20. Linet MS, Devesa SS, Morgan GJ: The leukemias. In Cancer epidemiologyand prevention.3rd edition.Edited by Schottenfeld D, Fraumeni J Jr. NewYork: Oxford University Press; 2006:841-871. 2006.

21. Bhutani M, Vora A, Kumar L, Kochupillai V. Lymphohemopoietic malignancies in India. Med Oncol.. 2002 Sep 1; 19(3):141-50.

22. Muhsin SY, Al-Mudallal SS. Expression of Aberrant Antigens CD7 and CD19 in Adult Acute Myeloid Leukaemia by Flow Cytometry.Iraqi J Hematology. 2014 Jan 1;3(1):1.

23. AlameriA,Khudhair M ,BatoolG,Murad N. Epidemiology of chronic myeloid leukemia in Iraqi patients. 14th Congress of the European Hematology Association Abstract Book haematologica 2009; 94(s2), p 578.

24. Şahin F, Saydam G, Cömert M, Uz B, Yavuz AS, Turan E, Yönal İ, Atay H, Keltikli E, Turgut M, Pehlivan M. Turkish chronic myeloid leukemia study: retrospective sectional analysis of CML patients. Turk J Haematol. 2013 Dec; 30(4):351.

25. National Cancer Institute, Cancer Stat Facts (2015). Chronic myeloid leukemia [cited 2018 June 30].Available from:https://seer.cancer.gov/statfacts/html/cmyl.html.

26. Tardieu S, Brun-Strang C, Berthaud P, Michallet M, Guilhot F, Rousselot P, Sambuc R. Management of chronic myeloid leukemia in France: a multicentered cross-sectional study on 538 patients. Pharmacoepidemiol Drug Saf. 2005 Aug; 14(8):545-53.

27. Alwan AF. Assessment of cytogenetic response after treatment with imatinibmesylate in patients with chronic phase chronic myeloid leukemia. Iraqi J Hematology. 2014;3(1): 56-61.

28. American Cancer Society: Cancer facts \& figures 2012. Atlanta: American cancer society. [Cited 2018 July 13].Available from:http://www.cancer.org/research/ cancerfactsfigures/cancerfactsfigures/cancer-factsfigures-2012.

29. Naji AS. Outcome of 49 Iraqi adult patients with Chronic Lymphocytic Leukemia treated with oral alkylating agent. J Fac Med Baghdad. 2012; 54(2):126-30.

30. Pamuk ON, Pamuk GE, Soysal T, Ongören S, Başlar Z, Ferhanoğlu B, Aydin Y, Ulkü B, Aktuğlu G, Akman N. 
Chronic lymphocytic leukemia in Turkey: experience of a single center in Istanbul. South Med J. 2004 Mar; 97(3):240-5.

31. Saxena R, Kumar R, Sazawal S, Mahapatra M. CLL in India May Have a Different Biology from That in the West. Blood. 2016; 128(22): 5574.

32. Gogia A, Sharma A, Raina V, Kumar L, Vishnubhatla S, Gupta R, Kumar R. Assessment of 285 cases of chronic lymphocytic leukemia seen at single large tertiary center in Northern India. Leuk Lymphoma. 2012 Oct 1; 53(10):19615.

33. National Cancer Institute, Cancer Stat Facts (2015).Chronic lymphocytic leukemia[cited 2018 July 30]. Available from: https://seer.cancer.gov/statfacts/html/clyl.html.

34. World health organization, Union for International Cancer Control (2014) .Chronic lymphocyticleukemia[cited2018 August 2].Available from:http://www.who.int/selection medxicines/committees/expert/20/applications/CLL.pdf.

35. Central Intelligence Agency, WorldFact Book (2017).Age Structure [cited 2018 august 6]. Available from: https:// www.cia.gov/library/publications/the-world-factbook/geos/ iz.html.

\section{$(\theta)(1)$}

This work is licensed under a Creative Commons AttributionNon Commercial 4.0 International License. 